\title{
THE LEARNING PLATFORM IN DISTANCE HIGHER EDUCATION: STUDENT'S PERCEPTIONS
}

\author{
Dr. Maria Luz CACHEIRO-GONZALEZ \\ ORCID: http://orcid.org/0000-0001-7865-1362 \\ Universidad Nacional de Educacion a Distancia (UNED) \\ Madrid, Spain \\ Dr. Antonio MEDINA-RIVILLA \\ ORCID: http://orcid.org/0000-0002-1483-0668 \\ Universidad Nacional de Educacion a Distancia (UNED) \\ Madrid, Spain \\ Dr. Maria Concepcion DOMINGUEZ-GARRIDO \\ ORCID: http://orcid.org/0000-0003-1192-0040 \\ Universidad Nacional de Educacion a Distancia (UNED) \\ Madrid, Spain \\ Dr. Maria MEDINA-DOMINGUEZ \\ ORCID: https://orcid.org/0000-0003-3500-9913 \\ Universidad Antonio de Nebrija \\ Madrid, Spain
}

Received Date: 08/02/2018 Accepted Date: 25/05/2018

\section{ABSTRACT}

The aim of this study is to discover student's perceptions from the School of Education about the use of the learning platform to improve educational process in distance higher education. To this end, a descriptive study with a mixed approach (quantitative and qualitative) has been applied according to the objectives of the study. An ad-hoc semi-structured questionnaire has been validated by experts, obtaining the response of 111 students of the Spanish National University of Distance Education (UNED), who are conducting social education, pedagogy, and master's degrees in education. The results showed positive values in the different dimensions analyzed: (I) Role of learning platform in distance education, (II) Instructional of the design learning platform, (III) Didactic interaction through the learning platform and (IV) The learning platform and professional practice. The analysis of the open questions, provides guidelines for improving the use of the learning platform in distance higher education regarding strengths (student's exchange, and independent learning) and weaknesses (feedback delay, and content repository).

Keywords: Learning platform, ICT, student perception, higher education, distance education.

\section{INTRODUCTION}

Higher distance education offers a scenario for the development of teaching-learning processes through educational platforms and their functionalities for didactic communication, mainly online forum (Lopez, \& Camilli, 2014; Guedez, \& Navea, 2014; Bousbahi, \& Alrazgan, 2015; Bin, 2017). One of the challenges of the Distance Higher Education modality is to promote the advantages it offers to groups that do not have the opportunity to participate in other traditional models. This requires an adequate use of the potential of this methodology so that students can combine self-regulated and collaborative training processes, as well as 
training in digital competence that "become increasingly necessary to participate meaningfully in the new knowledge society and economy of the twenty-first century (INTEF, 2017, p. 5). Among the aspects that require constant updating in the use of the learning platform are: pedagogical functionalities, online instructional design, and didactic interaction. The development of the theoretical framework has allowed deepening aspects such as: ICT in Higher Distance Education, Technopedagogical Models, Design of online learning environments, and the learning platform components in higher education (Course components and Communication tools of learning platforms).

Quality of content and system interactivity through LMS has a major influence of students' initial perceptions of their satisfaction (Chugh, Ledger, \& Shields, 2017; Altunoglu, 2017; Baleghi, Ayub, Mahmud, \& Daud, 2017). The objective of this study is to discover student's perceptions from the School of Education about the use of the learning platform to improve educational process in distance higher education. The analysis of the strengths and weaknesses of the platform offers guidelines for an adequate integration of technological resources in distance education processes. Some Learning Management Systems (LMS) Trends are discussed for future research.

\section{THEORETICAL FRAMEWORK}

\section{ICT in Higher Distance Education}

The impact of information and communication technology (ICT) in the knowledge society is producing a permanent revolution in the different sectors (Pavel; Fruth \& Neacsu, 2015) and requires a new approach to education, focused on the use of open content and resources (Knyazeva, 2016) mainly based on the possibilities of the web 2.0 cloud technologies (wikis, blogs, and social networks) (Barak, 2017; Moreira, Henriques, Goulão, \& Barros, 2017), promoting "persistent connectivity, enabling students and educators to access and contribute to shared workspaces, anytime" (Adams et al, 2017, p.20). Keane, Keane, \& Blicblau (2016) emphasize that the use of ICT by students contribute to the development of the 4Cs (creativity, communication, collaboration and critical thinking), essential in the 21 st century, in combination with the $3 R s$ (reading, writing and arithmetic).

Higher education students have at their disposal a variety of ICT resources offering integrated media typologies, as RICA (Information, Collaboration and Learning) (Cacheiro, 2011), or SECTIONS (Students, Ease of use, Costs, Teaching functions, Interaction, Organizational issues, Networking, and Security and privacy) (Bates, 2015). This plurality of learning resources (apps, edublogs, social networking, and websites) (Brazuelo \& Cacheiro, 2015) require an extensive use by teachers in co-involvement with students, the real protagonists, prosumers now. Sometimes, students manifest more satisfaction with the Social Networking Sites (SNS) than by traditional Learning Management System (LMS) (Pilli, 2014).

ICT development towards the knowledge-based society include three stages: ICT Readiness (level of networked infrastructure and access to ICT); ICT Intensity (level of use of ICT in the society) and ICT Impact (results/outcomes of effective and efficient ICT use) (Pavel; Fruth \& Neacsu, 2015). In the full democratization of knowledge, it is necessary to promote open learning environments with the appropriate tutorial advice, which makes possible the purpose of higher education. Four rationales for ICT integration in education are presented by Jain \& Tyagi (2017): social (need for familiarizing students with technology), vocational (preparing students for jobs that require skills in technology), catalytic (utility of technology to improve performance and effectiveness in teaching), and pedagogical (to utilize technology in enhancing learning, flexibility and efficiency in curriculum delivery).

Distance education practices focus on identifying the educational potential of technology and assume a transformative role of students towards self-regulated learning strategies (Zimmerman, 1990), providing the foundation for new generations of learning (Scoppio \& Luyt, 2017). The study by Topchyan and Zhang 
(2014) has validated some factors that affect the perception of distance education students to develop the competences to work in virtual learning teams, which are: loyalty, integrity, conscientiousness, communication, cooperation, creativity, learning motivation, persistence, independence, and intercultural communication.

The plurality of web resources integrated on virtual learning platforms provides opportunities to select and adapt information, collaboration and learning resources. Nevertheless, some results indicate that university students tend not to use these technologies to regulate their own learning process (Yot \& Marcelo, 2017). Henderson, Selwyn \& Aston (2017) suggest that digital technologies are not 'transforming' the nature of university teaching and learning.

Online learners pay attention to structure and leadership of virtual learning environments to take a deep and meaningful approach to learning (Garrison \& Cleveland, 2010). A systematic review from 1995 to 2014 (Martin, Ahlgrim \& Budhrani, 2017) conclude that it was not clearly distinguishable whether the Synchronous Online Learning technology was used for disseminating the content or whether it was used to allow students to interact with each other or the material. Research from different authors (Prendes \& Gutierrez, 2013, ITU-UNESCO, 2014, and Kebble, 2017) considers that ICT should promote interactivity favoring forms of communication in the knowledge society. The time dedicated to communication activities by students has been considered as a predictor of academic performance (Rienties \& Toetenel, 2016). Selection, adoption and adjustment of ICT tools promote openness to a permanent change, rediscovering the most valuable goals of academia, and the continuous improvement of teachers and students.

\section{Technopedagogical Models}

Technopedagogical models like the TPACK (Technology, Pedagogy and Content Knowledge) (Mishra \& Koehler, 2006) and SAMR (Substitution, Augmentation, Modification \& Redefinition) (Puentedura, 2014, 2016), offer a framework to make decisions in order to incorporate the use of ICT as a didactic experience.

\section{TPACK Model}

The teaching profession in the words of Shulman (2015) is "magical" and requires "embracing uncertainty" through a reciprocal commitment between the teacher and the students. This author has promoted the need to combine knowledge of content and pedagogy by coining the term PCK (Pedagogical Content Knowledge), which has been the precursor of the TPACK model (Technology, Pedagogy and Content Knowledge) from Mishra and Koehler $(2006,2008)$ which incorporates the technological knowledge applied to the teaching-learning process. The TPACK model (Mishra \& Koehler, 2006, 2008) offers different combinations among the types of knowledge of the model: curricular, pedagogical, and technological, based on the application contexts. The dimensions offered by the model are seven: CK (Content Knowledge), PK (Pedagogical Knowledge), TK (Technological Knowledge), CPK (Pedagogical Content Knowledge), TCK (Technological Content Knowledge), TPK (Technological Pedagogical Knowledge), and TPCK (Technological Pedagogical Content Knowledge). The TPACK model, widely disseminated internationally, provides different strengths and opportunities through the questionnaires developed to analyze the level of mastery in the integration of ICT (Schmidt et al., 2009; Cabero, 2014), allowing the design of teaching strategies to reinforce the types of knowledge less developed.

\section{SAMR Model}

The SAMR (Substitution, Augmentation, Modification and Redefinition) model is based on different phases from substitution (initial contact with technology) to redefinition (mastery of educational technology). The first two phases correspond to the process of improvement in the way of integrating ICT, and the next two phases are in the process of transformation. Each phase can be characterized by the role of technology in the teaching practice (Puentedura, 2016): 
Substitution. Technology acts as a direct tool substitute, without any functional change.

$>$ Augmentation. Technology acts as a direct substitute tool, with functional improvement.

$>$ Modification. The technology allows redesigning important task.

$>$ Redefinition. Technology allows the creation of new tasks, previously inconceivable.

In this context, it is favored to incorporate into the teaching-learning process resources adapted to the objectives (from memory to creation), to the level of competence (from substitution to redefinition), and to the investigative process (from research to share). These models can be considered conceptual frameworks that offer a comprehensive vision of different relevant elements to consider when applying technologies in the educational context.

\section{Design of Online Learning Environments}

Conner (2013) highlights the plurality of contexts and diversity of ways of learning that occur in the knowledge society from formal to informal, from intentional to unexpected, which are represented in the following diagram (Figure 1).

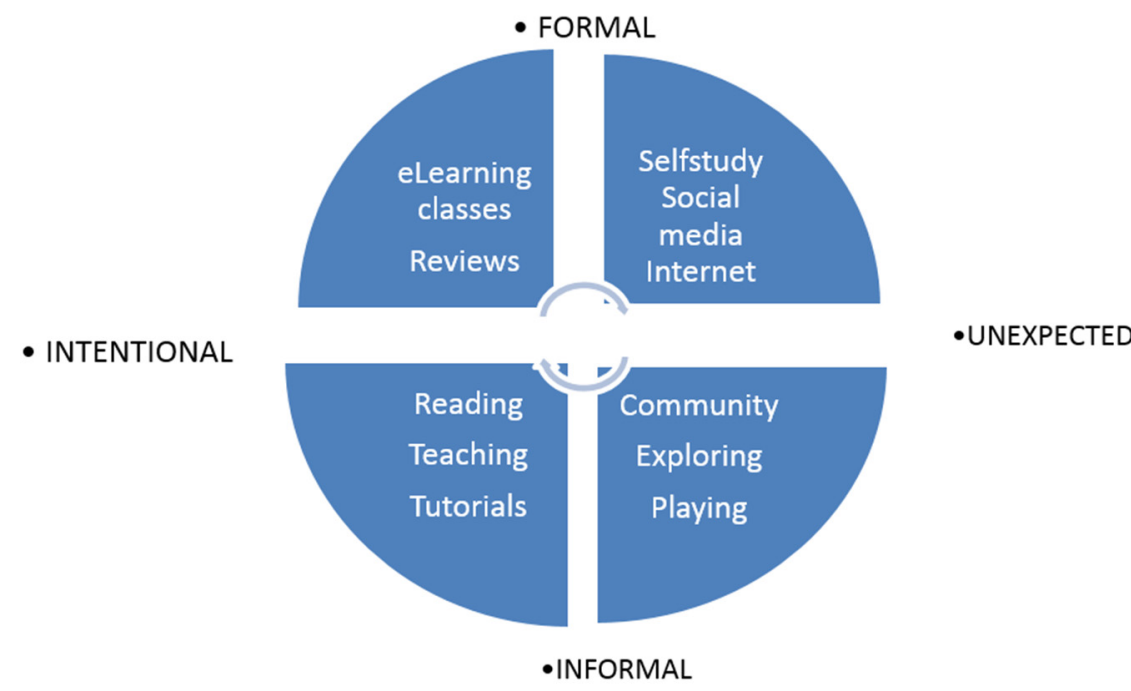

Figure 1. Ways to learn in the knowledge society (Conner, 2013)

The synthesis processes of teaching quality presences in online environments are made explicit by Garrison $\&$ Anderson (2005, p. 52), evaluating three types of: cognitive, social and teaching (Table 1).

Table 1. Educational interaction in online learning environments (Garrison \& Anderson, 2005)

\begin{tabular}{clll}
\hline \multicolumn{1}{c}{ Elements } & \multicolumn{1}{c}{ Categories } & \multicolumn{1}{c}{ Indicators } \\
\hline Cognitive presence & Triggering event: & - Feeling of perplexity. \\
& - Exploration. & - Exchange of information. \\
& - Integration. & - Association of ideas. \\
Social presence & - Resolution. & & \\
& - Affective dimension. & - Expressing emotions. \\
Teaching presence & - Open communication. & - Express themselves freely. \\
& - Cohesion of the group. & - Promote cooperation. \\
& - Discursive elaboration. & - Establish the program content and \\
& & - methodology. \\
& & - Fonstruct meaning together. \\
\hline
\end{tabular}


These three elements and their interactions offer a landscape to analyze educational interaction inside online learning environments. It is necessary to find a synthesis between innovation and research practices in Distance Higher Education. Evidence in this respect is provided by Zanjani, Edwards, Nykvist, \& Geva (2016) who find that designing appropriate tasks and assessment procedure are determinants for engaging students with the Learning Management System. Online learning environments must have: quality, certification and affordability, which is based on the rigor of institutions. Digital learning (a new version of distance education) is assuming an educational disruption because it raises a drastic change of supports and methods and because progressively it is gaining space in conventional formats, this author arriving to collect more than 20 causes that advance to great pace of educational proposals at a distance: openness, flexibility, ubiquity, self-control, immediacy, etc. (Garcia-Aretio, 2017). Johnson, Adams, Cummins, Estrada, Freeman $\&$ Hall (2016) state that educational institutions and particularly university in the today world combine classroom and online courses. Mirriahi, Alonzo, McIntyre, Kilobyte \& Fox (2015) present some principles and implications to be consider for the design of effective online learning programs (Table 2).

Table 2. Principles in designing online programs (Based on Mirriahi et al., 2015)

\begin{tabular}{ll}
\hline \multicolumn{1}{c}{ Principle } & \multicolumn{1}{c}{ Implications for design } \\
\hline Active engagement. & $\begin{array}{l}\text { The teaching staff can engage in an active process and } \\
\text { become aware of new ideas or experiences. }\end{array}$ \\
$\begin{array}{l}\text { Extract of the practice and the previous } \\
\text { knowledge in authentic environments. }\end{array}$ & $\begin{array}{l}\text { The teaching staff can reflect and draw from their own } \\
\text { practice, their work and their colleagues the most valuable. } \\
\text { Program facilitators present and provide new guidelines for } \\
\text { Understanding expectations. }\end{array}$ \\
$\begin{array}{l}\text { action. } \\
\text { Respect and satisfaction with the diverse } \\
\text { apprentices. }\end{array}$ & $\begin{array}{l}\text { The program models influence learning environments where } \\
\text { staff feel valued and respected. }\end{array}$ \\
\hline
\end{tabular}

The use of online systems in universities must be supported by the authorities of the institution and recognized the efforts undertaken by the faculty. Mirriahi et al. (2015) are questioning that online programs must consider the principles of flexibility, b-learning modeling, flipped classroom, inclusivity, scalability, efficiency and cost-effectiveness. It is intended that the course design on the learning platform is intuitive and that students understand and properly use links and possible scenarios that must work and interact with faculty and all participants.

\section{The Learning Platform Components in Higher Education}

The learning platform is a way of structuring the instruction that fosters optimal organization of content and interaction with students, and it is used by most of the Universities (Gomez, 2016; Almarashdeh, 2016). Teaching must take advantage of virtual environments (Moreira, Henriques, Goulão \& Barros, 2017; JuYin \& Yen-Chen, 2016; Marin, Sampedro, \& Vega, 2017) and adapting the discourse to the uniqueness of the virtual environments complexity. Learning platforms have been presented as virtual scenarios that promote educational innovation and professional development (Prendes \& Gutierrez, 2013, Sáez, Dominguez, Ruiz \& Belando, 2014), more focused on the model of educational personalization, with emphasis on cooperation.

\section{Course Components of Learning Platforms}

The learning platform in distance higher education must be adapted to the knowledge and practices of virtual environments (e-Learning and b-Learning), promoting usefulness (Moreno, Cavazotte \& Alves, 2017), autonomous learning (Cho, 2011, Zhu, Au \& Yates, 2016), and interaction with teachers throughout learning tasks and communication tools (Ma, Han, Yang \& Cheng, 2015; Gharmallah, 2017). In this line, 
Benedetti (2015, p. 174) presents a map to know the student's navigation processes, following the cognitive style to understand and take better decisions to advance in the domain of the virtual course (Table 3).

Table 3. Student's navigation processes (Benedetti, 2015)

\begin{tabular}{ll}
\hline Process & Description \\
\hline Understanding & $\begin{array}{l}\text { Overview of the course structure. } \\
\text { All parts / areas of the course are visible. }\end{array}$ \\
Instructional & $\begin{array}{l}\text { Organization logical course. } \\
\text { Easy access to components of the course. } \\
\text { Functional }\end{array}$ \\
& $\begin{array}{l}\text { The course links operate correctly. } \\
\text { The course content levels are accurate. }\end{array}$ \\
\hline
\end{tabular}

According to the study of Holzweias, Joyner, Fuller, Henderson \& Young (2014), online graduate students' perceptions refer to their best learning experiences through activities that allow them to share knowledge and reflect among others. The teaching-learning process mediated by the learning platform includes substantial diversity of educational components to the communicative act: masterclass, knowledge presentation and questioning (Figure 2).
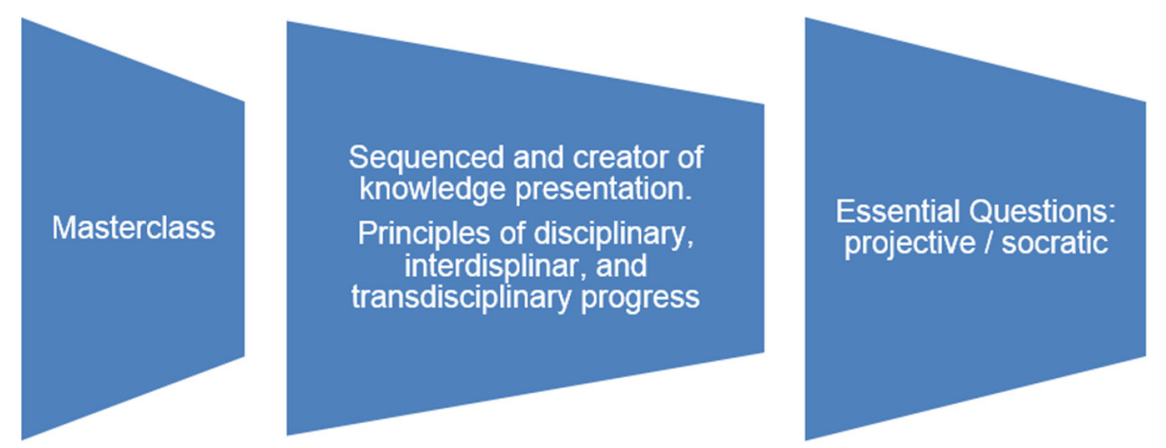

Figure 2. Communicative act in the teaching-learning process

Medina, Sánchez \& Campos (2014), Medina and Dominguez (2015), and Medina, Cacheiro \& MedinaMedina (2015) have stressed the value of communicative competence of teachers and impact on the development of educational processes, making progress in achieving to harmonize the instructive-creative design, to be worked on virtual environments. The educational use of learning platforms, respond to the challenges of distance higher education, customizing tasks, and adapting content presentation to the virtual support, combining with traditional materials (Medina \& Dominguez, 2015; Oproiu, 2015).

\section{Communication Tools of Learning Platforms}

The use of learning platform encourages the interaction of all components of a traditional didactic scenario: teacher, students and subject matter (Figure 3).

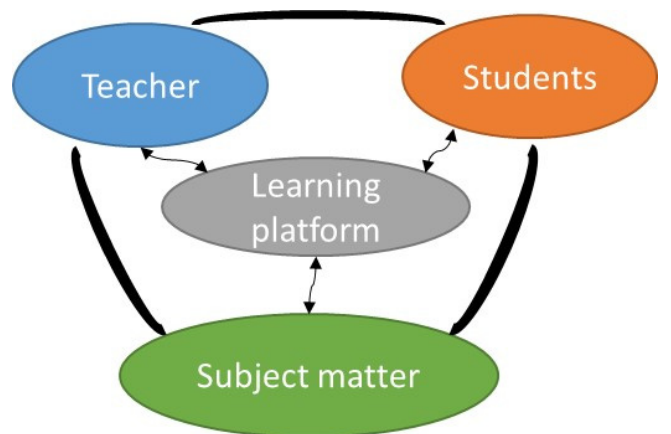

Figure 3. Components of a ICT learning scenario 
The interaction among the various components is essential to promote a mediated learning (Bates, 2015). The learning platform opens a new stage, which exceeds the traditional space-time to motivate and make available to students, colleagues and various groups, a set of instructional options.

The most important communication features of the platforms include forums, chat and webconference.

$>$ Forums. Virtual scenarios for comments, reflections between teachers and students in asynchronous mode.

$>$ Chat. Written speech involving a group of students and teachers in synchronous mode.

$>$ Webconference. Synthesizes the keys of the oral discourse, supported on transparencies, pictures, video tutorials, etc., expanded with questions, and comments from teacher and students.

Online discussions carefully monitored by instructors promote co-constructed knowledge through activities as: sharing, negotiating, elaborating, evaluating, etc. (Ioannou, Demetriou \& Mama, 2014) and facilitates students' higher order thinking (Kwon \& Park, 2017). When teachers give importance to collaborative learning, students are more aware of their benefit (Gomez, Barbera \& Fernández, 2016).

The interaction in online forums helps students to exchange different points of view of a subject (Duran, Cornejo, \& Flores, 2017). One of the advantages of online forums following Arasaratnam \& Northcote (2017) is having time for reasoned comments, meanwhile in the face-to-face sessions may not always be possible. Learning platforms seek to exploit the most valuable aspects of the training scenarios to become open spaces to the intellectual and emotional enjoyment of all participants, taking advantage of the communication resources.

\section{LMS Trends}

Some leaders believe Learning Management System (LMS) are limited to the administration aspects rather than the learning itself (Adams et al, 2017). "Learning ecosystems must be agile enough to support the practices of the future. In using tools and platforms like LMS, educators have a desire to unbundle all of the components of a learning experience to remix open content and educational apps in unique and compelling ways". (Adams et al, 2017, p. 2). To address this limitation, Brown, Dehoney, \& Millichap (2015) have adopted the term next generation digital learning environment (NGDLE) as an evolution of the current LMS. NGDLE is a dynamic and interconnected ecosystem ever-evolving community of learners, instructors, tools, and content (Table 4).

Table 4. NGDEL Characteristics and Functional domains

\begin{tabular}{ll}
\hline \multicolumn{1}{c}{ Characteristics } & \multicolumn{1}{c}{ Functional domains } \\
\hline A confederation of IT systems. & Interoperability and Integration of tools. \\
Full adherence to standards for interoperability. & User personalization. \\
Support personalization. & Analytics, Advising, and Learning Assessment. \\
A cloud-like space. & Collaboration at multiple levels making it easy to \\
& move between private and public digital spaces. \\
& Accessibility and Universal Design Approach. \\
\hline
\end{tabular}

The model for the NGDLE architecture could be considered as a mash-up using heterogeneity of components to produce homogeneity of function (Brown, Dehoney, \& Millichap, 2015). In this same line are the developments of the cloud learning environments (CLE), including web 2.0 applications that favor a pedagogical framework for technology-integrated social constructivism, in which students are active learners and creators of knowledge (Barak, 2017). 


\section{Research Objectives}

The main research objectives of the study were:

$>$ Objective 1. To identify the student perceptions using learning platform in distance education.

$>$ Objective 2. To analyze the didactic interaction through the learning platform.

$>$ Objective 3. To propose keys to instructional design of the learning platform: course components and communication tools.

\section{METHOD}

The methodological approach used to meet the research objectives of the research integrates a quantitative and qualitative data analysis (Valles, 1997; Anderson, 1990; Garcia-Cabrero, 2009), benefiting from a mixed method approach and action research (Creswell, 2012). A descriptive scope and a transversal design, has been applied that "seeks to specify properties, characteristics and important features of the phenomenon under analysis" (Hernández-Sampieri et al., 2010, p. 80) and provides a basis for an appropriate solution to the problem of study.

A non-probability incidental sampling of undergraduate and postgraduate students from the UNED School of Education ( $\mathrm{n}=111)$, took place on this study. The questionnaire content validity has been assured through consultation with experts, who have reviewed the clarity, adequacy and internal consistency of the items based on their experience. It has also analyzed the reliability through the Cronbach's alpha internal consistency coefficient, obtaining values between 0.60 and 0.80 in the different dimensions, considered adequate for descriptive studies. The methodological rigor applied is in line with the proposals of GarciaCabrero (2009) and Creswell (2012), through the analysis of quantitative and qualitative data obtained through the questionnaire, allowing knowing the experiences of the participants on the use of the aLF learning platform. Meanwhile, content analysis has deepened in the experiences expressed by participants in the open questions, avoiding premature judgments (Gurtler \& Huber, 2007). Triangulation of the most representative results of closed and open questions is a contribution to the replicability of the study, in line with the contributions of Reichardt \& Cook (1986).

\section{RESULTS}

\section{Characterization of the Participants}

The participants are 111 higher education students of the UNED School of Education using the aLF learning platform, being $19 \%$ men and 81\% women, with an average age of 35, ranging from 19 to 55 years old. Respondents are mainly pursuing an Education Master's degree (59\%), otherwise the degree of Social Education (30\%), and fewer of Pedagogy (7\%) and other education studies (4\%). These students have used the platform an average of 2 years, specifically for 1 year (41\%), 2 years (19\%), 3 years $(20 \%)$ and more than 4 years $(20 \%)$, with a periodicity of consultation that goes from daily $(48 \%)$, weekly (45\%), biweekly (4\%) and monthly (3\%). Students check the learning platform: daily (48.6\%), weekly (44.1\%), biweekly (3.6\%), and monthly (3.6\%).

In addition to the learning platform, students demonstrate use of external communication tools, such as Facebook (52\%), WhatsApp groups (39\%), google+ (9\%), twitter (8\%), and some others as Skype, wikispaces, google drive, etc. The average years of professional experience in education of the group is 4 , being $1-4$ years (33\%), 5-10 years (26\%), more than 10 years $(19 \%)$, and some inexperienced $(22 \%)$. The professional educational level in which participants are involved are diverse, both formal: child (8\%), primary $(19 \%)$, secondary $(11 \%)$, vocational training (12\%), university $(22 \%)$; and non-formal (adults, associations, foundations, etc.) (23\%). 


\section{Results of the Closed and Open Questions of the Questionnaire}

The questionnaire scale used has the values 1 to 6 (1=strongly disagree, $2=$ quite disagree, $3=$ somewhat disagree, $4=$ somewhat agree, $5=$ quite agree and $6=$ strongly agree). In the analysis, the average value obtained in the item on the scale is provided, and to facilitate interpretation have been grouped the results of the options 1,2,3 (disagreement) and 4,5,6 (agreement) for each dimension of the questionnaire. The percentages of each of the values of the scale are found in Annex I.

\section{Dimension I: Role of Learning Platform in Distance Education}

In this dimension, there are 9 items related to different aspects about the role of learning platform: motivation, availability of course materials, promote independent learning, use by teachers, efforts to locate relevant information, complementarity with traditional materials, critical thinking, interaction among agents of the course and its role in distance education. The median value of the items is 4, except for item 3 which is 5 (Figure 4).

1. The learning platform motivates for the learning of the subject.

2. The learning platform facilitates the availability of course materials.

3. The learning platform promotes autonomous learning.

4. The learning platform has been successfully incorporated by the teaching staff.

5. The learning platform requires effort to locate the relevant information

6. The learning platform is a complement to the classic materials of the course.

7. The learning platform encourages critical thinking

8. The learning platform favors the interaction between the different agents of the course.

9. The use of the learning platform should be mandatory in distance education.

\begin{tabular}{|c|c|}
\hline $26,1 \%$ & $73,9 \%$ \\
\hline $18,9 \%$ & $81,1 \%$ \\
\hline $13,5 \%$ & $86,5 \%$ \\
\hline $27,9 \%$ & $72,1 \%$ \\
\hline $44,1 \%$ & $55,9 \%$ \\
\hline $44,1 \%$ & $55,9 \%$ \\
\hline $30,6 \%$ & $69,4 \%$ \\
\hline $21,6 \%$ & $78,4 \%$ \\
\hline $29,7 \%$ & $70,3 \%$ \\
\hline
\end{tabular}

口isagreement (1-2-3) घ Agreement (4-5-6)

Figure 4. Dimension I. Role of the learning platform in distance education (items 1-9)

Students overwhelmingly agree that the learning platform "promotes autonomous learning" (item I3, agreement=86.5\%), "facilitates the availability of course materials" (item 2, agreement=81.1\%) and "favors the interaction between the different agents of the course" (item 8, agreement=78.4\%). Some of the less agreement values correspond with "effort to locate the relevant information" (item 5, disagreement=44.1\%), and "complement to the classic materials of the course" (item 6, disagreement=44.1\%).

In the open question within this dimension, students have mentioned strengths of the learning platform as: student's exchange, availability of course materials, and independent learning. Some comments are:

Being able to interact and share experiences all students is very motivating. It is also an important element that facilitates the learning subject material. [E60]

It provides basic information (subject guide, manual and other materials) to study subjects and allows exposure of questions and comments from peers. [E83]

Aid to be autonomous in the management of information, as it cannot be otherwise in a virtual and distance environment. [E77] 
In this dimension, students have also shown weaknesses of the learning platform as: delay in responding teachers to the forums, too much informational noise, under-utilization of the platform as a mere content repository. Some comments are:

The delay in receiving answers to doubts, on the part of the teaching team, or the little solidarity among students by not helping others with doubts or problems that arise, creates a feeling of significant loneliness. [E77]

Regarding the forums, when the number of participants is very high it is impossible to read each of the messages from peers. [E60]

Forums holdings are long texts that don't incite debate. The materials are usually books, so don't promote link to related materials. [E72]

There is used only to deposit materials and do not promote communication among students. [E17]

\section{Dimension II: Instructional Design of the Learning Platform}

In this dimension, the items are organized into two thematic blocks. In a first block (items 10-15) course components are analyzed: study guide, contents, supporting documents, tasks, and self-evaluation activities. The median value of the items is 4, except for item 13 and item 15 which is 5 (Figure 5).

10. The didactic guide offers the key aspects for the development of the subject.

11. The contents selected are relevant to an in-depth knowledge of the subject.

12. Online supplementary documents add value to the course's classic materials.

13. The tasks of the learning platform allow to deepen the mastery of the contents.

14. The self-assessment activities in the learning platform promote the acquisition of the knowledge of the subject.

15. The feedback to the tasks sent in the platform contributes to the improvement of the learning.

\begin{tabular}{|r|c|}
\hline $16,7 \%$ & $82,2 \%$ \\
\hline $23,3 \%$ & $75,5 \%$ \\
\hline $16,6 \%$ & $83,4 \%$ \\
\hline $18,9 \%$ & $80,1 \%$ \\
\hline $18,9 \%$ & $76,7 \%$ \\
\hline $14,4 \%$ & $85,6 \%$ \\
\hline
\end{tabular}

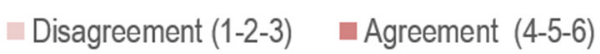

Figure 5. Dimension IIa. Instructional design of the learning platform: course components (items 10-15)

All answers in this block have a higher agreement value. Some of these items are the importance given to the feedback to the tasks (item 15, agreement $=85.6 \%$ ), the supplementary documents (item 12, agreement $=83.4 \%$ ), the study guide (item 10 , agreement=82.2\%) and instructional tasks (item 13, agreement $=80.1 \%)$.

The second block (items 16-20) of this dimension is about the learning platform communication tools (forum, chat, and webconference). The median value of all the items is 4 (Figure 6). 
16. The platform teaching team forum offers possibilities to comment basic contents of the subject.

17. The platform students' forum (cafeteria) offers a space for collaborative learning.

18. The platform chat facilitates the agile resolution of your doubts in your learning.

19. The platform web conferencing favors the creation of an affective bond with the teacher throughout the learning process.

20. The participation in networks of teacher innovation through the platform allows to continue reflecting on the subject in a broader context.

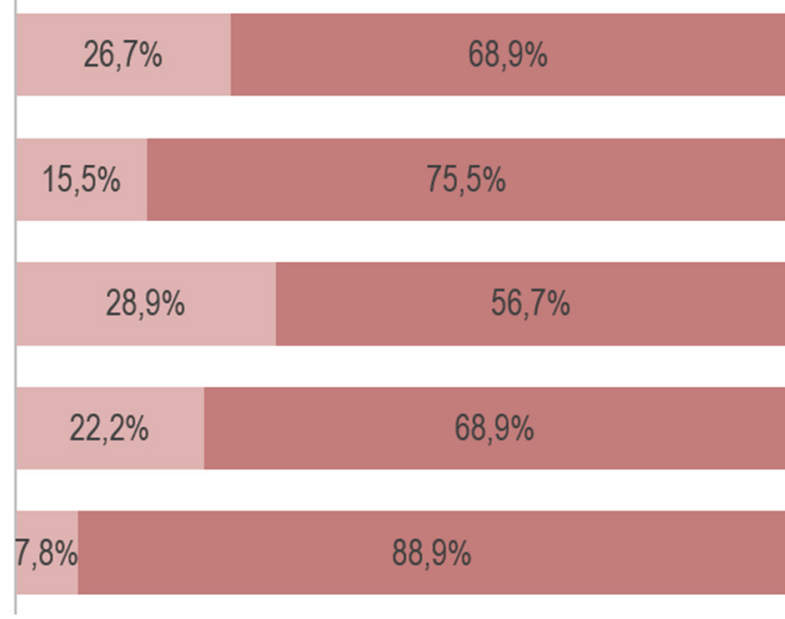

口isagreement (1-2-3) $\quad$ agreement (4-5-6)

Figure 6. Dimension IIb. Instructional design of the learning platform: communication tools (items 16-

20)

Answers in this block of items stresses student participation in social networks (item 20, agreement $=88.9 \%$ ), and the importance given to student forum (item 17, agreement $=75.5 \%$ ). The lowest score is the chat as a medium for the resolution of doubts (item 18, disagreement=28.9\%).

In the open question within this dimension, students are asked to describe and justify the components of the learning platform that have made it more educational value to their learning. Among the responses it is highlighted the importance of: peer learning through the forum, and resolving doubts through webconference. Some comments are:

I appreciate the forums within each subject because allows interaction of students. Each of us can contribute their views and experience in the subject matter. In my opinion, this enriches my learning a lot. [E22]

Forums, can interact and help my teammates and communicate with my teachers. I love forums and actively participate in them, not to solve my doubts, but to help colleagues who have more difficulties than me. [E42]

Webconference, as the students' questions are answered at the time, and you know questions or contributions from other students. [E70]

In the open question about reflections to improve teaching platform design, students identified proposals in relation to navigation menus, uniformity in the design of the courses, and the possibility of performing teamwork. Some comments are:

Improve the user experience in access to menus, you have not come and go when you want to change the field to work. [E03]

A uniform format for all courses greatly facilitates the student's work, while providing an orderly educational structure. [E27]

To work in groups using other tools. [E90]

\section{Dimension III: Didactic Interaction through the Learning Platform}

In this dimension, there are 6 items related to aspects that contribute to online didactic interaction. The median value of the items is 4, except for item 21 and item 24 which is 5 (Figure 7). 
21. The learning platform has introduced a new culture in distance education processes.

22. Teachers use the learning platform to respond to the needs of distance education.

23. The learning platform facilitates the relationship between all course participants.

24. The learning platform favors the creation of a scenario of possibilities of collaboration between equals.

25. The learning platform fosters a climate of didactic interaction between teachers and students.

26. The learning platform enables the creation of learning communities among students.

$$
\text { - Disagreement (1-2-3) }
$$

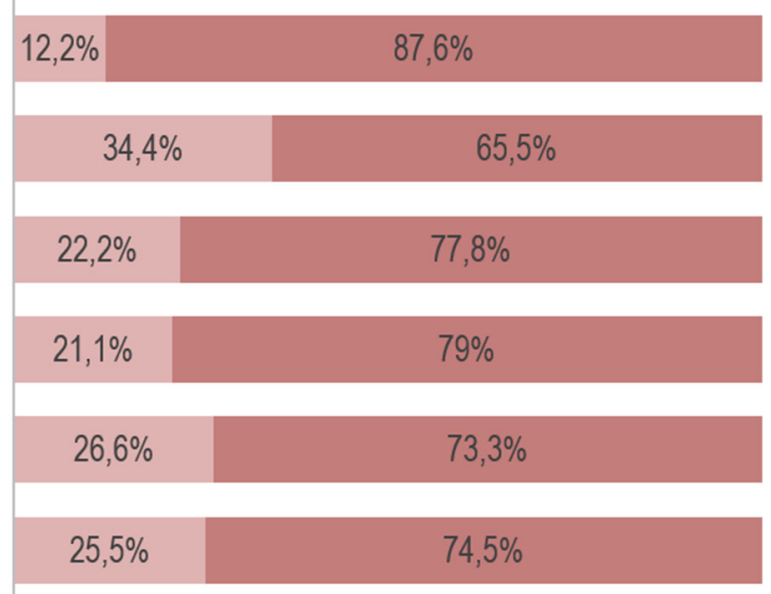

- Agreement (4-5-6)

Figure 7. Dimension III. Didactic interaction through the learning platform (items 21-26)

The items with a higher agreement are that "the learning platform has introduced a new culture in the process of distance learning" (item 21, agreement=87.6\%), and the lowest degree of agreement is the use of the learning platform by teachers to meet the needs of distance education (item 22, disagreement $=34.4 \%$ ). In the open question for this dimension, students are invited to narrate the main tasks that teachers carried out to improve the educational interaction through the learning platform. In this sense, their comments focus on: avoid abandonment, promote dialogue and raise interactive activities. Some comments are:

To create a classroom environment, although the modality was at distance. Otherwise the dropout rate increases significantly. [E27]

Having a fluid "dialogue" with students through forum posts, etc. [E42]

Propose interactive activities through the forum and send questions about any text or reading to share views and respond to them among students. [E71]

\section{Dimension IV: The Learning Platform and Professional Practice}

In this dimension, there are 7 items on aspects that contribute to the present or future professional practice. The median value of the items is 4 , except for item 33 which is 5 (Figure 8).

27. The learning platform enables a fruitful dialogue with teachers for professional practice.

28. Through the learning platform, strong links with other students are encouraged for future projects.

29. The learning platform promotes a collaborative learning style of interest for your professional practice.

30. The training platform promotes a collaborative learning style of interest for their professional practice.

31. Satisfaction is perceived in using the learning platform as a means to improve ongoing training processes.

32. The use of the learning platform with the classical materials (texts, ebook, guides, etc.) is appropriately.

33. The learning platform constitutes an essential didactic resource in distance education.

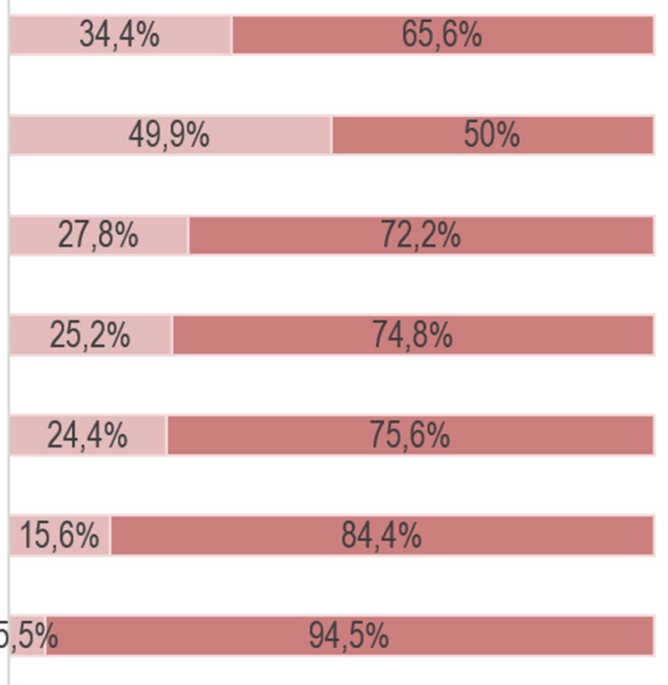

= Disagreement (1-2-3) = Agreement (4-5-6)

Figure 8. Dimension IV. The learning platform and the professional practice (items 27-33) 
Items with more agreement are "The learning platform constitutes an essential didactic resource in distance education" (item 33, agreement $=94.5 \%$ ), and "combine the learning platform with classic materials "(item 32 , agreement $=84.4 \%)$. The item with lowest degree of agreement is "through the learning platform links with other students for future projects are favored" (item 28, disagreement=49.9\%).

In the last two open questions respondents are asked to describe and justify the opportunities and threats of the learning platform based on their academic experience. Among the opportunities arising from proper use of the learning platform, students mentioned: access to higher education, interactivity, training, knowledge sharing and creation of a virtual learning community. Some comments are:

Interactivity, as knowledge is shared through forums among students and teachers. [E03]

Access to training processes of people who, by personal, work, family, etc. circumstances, could not access to training activities. [E06]

Continue professional training from anywhere in the world. [E56]

Appropriate use of the learning platform opens a new world of opportunities both classroom training, and distance. It also contributes to the new teaching models to promote active student participation in their training. [E27]

The well-used and encouraged platform by the faculty can give us a very useful asynchronously learning, using teachers and student's resources who wish to contribute with knowledge gained or links of interest to other colleagues. [E39]

I believe that everyone who entered the virtual training are mature and responsible enough to give an excellent use of this resource that becomes the only opportunity for improvement for some people. [E53]

Feeling member of a virtual community of learning. Meet "virtually" companions from other places and even make virtual friendships that endure over time. [E42]

Among the threats arising from a misuse of the learning platform, participants say: lack of motivation, digital immigrants, mismanagement forum posting, lack of space to know the profile of other participants. Thus, they manifest:

The biggest threat is not get motivated to go ahead with the studies. [E2O]

Improper use of the platform can result in a large drop formation by the students, especially in the form of distance learning. [E27]

Too much informative noise in the messages. [E43]

I think that should facilitate the relationship among students to promote collaboration. [E72]

When there is a lack of appropriate strategies for the use and management of new information technologies in people who, like me, were born during the 60s and are at a disadvantage with other more competent younger digital native's students and the use of what relates technologies. [E77]

\section{DISCUSSION AND CONCLUSIONS}

The discussion of the results and the main conclusions of the study are organized according to the research objectives. In relation to the Objective 1 "To identify the student's perceptions using learning platform in distance education", students agree that learning platform promotes autonomous learning $(86,5 \%)$, facilitates the availability of course materials $(81.1 \%)$, and favors interaction among the different agents of the course (78.4\%). These aspects are also highlight by Kurucay \& Inan (2017) that considered the learning platform is a means to manage the basic elements of the course: content, activities and evaluation through independent and self-regulated learning, enabling communication with faculty and peers. Dahlstrom, Brooks, \& Bichsel (2014) find that students who use the LMS are satisfied with their experience related to accessing course content, and less about collaborating on projects for study groups with other students. 
Added evidence in this respect is provided by the review carried out by Henderson, Selwyn \& Aston (2017) and Bartolomé, Garcia \& Aguaded (2018) that conclude that universities would be well advised to continue to develop their repositories of digital resources, improve the reliability and 'user-friendliness' of learning management systems. However, Selwyn (2016) highlights four distinct types of digital 'downside': distraction, disruption, difficulty and detriment.

In relation to the Objective 2 "To analyze the didactic interaction through the learning platform", participants stress the need to enrich the courses with guided discussions aimed to create situations of dialogue and exchange, and emphasizes the importance of proper use of this scenario to become familiar with the new culture of distance learning processes. The opportunities offered by the learning platform to collaborate among students is highly valued in our study (79\%), in line with the results obtained by Maita \& Navea (2014) who point out the platform is considered by students as a way to improve the interaction between students and teachers, both bilateral and multilateral. These findings are consistent with the results by Altınay (2017) who found that the collaborative online peer learning process in higher education encourages critical reflection and self-assessment. Nevertheless, Gomez; Barbera \& Fernández (2016) find that students are more concerned with their own learning benefits than the collaborative variables.

Students mentioned among the opportunities of the learning platform the creation of a virtual learning community. As note by Lyashenko \& Frolova (2014) and Moreira, Henriques, Goulão, \& Barros (2017), virtual platforms enforce collaboration of adults and young learners in universities. In this regard, it is important to promote a scenario that facilitates the creation of social and collaborative learning environments (Zapata, 2011; Zagalsky, Feliciano, Storey, Zhao \& Wang, 2015; Fields, Lai, Gibbs, Kirk \& Vermunt, 2016) or being part of a learning cyber community (Murua, Cacheiro \& Gallego, 2014), to encourage student participation in online seminars (Falloon, 2011). Examining articles published between 2011 and 2015 about interaction in distance education environments, the results revealed that researchers continue to pay attention to interaction, mainly learner-learner (Karataş, Yılmaz, Dikmen, Ermiş, \& Gurbuz, 2017). Empirical research on learner-content interaction is needed to improve the design and production of distance learning courses (Xiao, 2017).

In relation to the Objective 3 "To propose keys to instructional design of the learning platform: course components and communication tools", the educational use of the platform becomes a means of technological literacy and for the development of communication skills apply to students whose main horizon is teaching. In this line are the research of Garrison \& Anderson (2005) and Benedetti (2015) to maximize the possibilities of virtual teaching. This requires the design of motivating tasks taking into consideration the different elements of each component of the platform following the proposals of Mishra \& Koehler (2006) and Puentedura (2014) combining subject matter, pedagogy and technological aspects. One proposal in this regard is that of Shaw, Larson \& Sibdari (2014) on Guided Learning Pathways, contributing to personalize content and activities in learning platforms based on the interests and student motivation.

Learning platform design must consider student's FODA analysis based on the strengths, weaknesses, opportunities and threats, and represented in the following network (Figure 9). Students manifest the use of other external web 2.0 tools and social networks. This finding is in the line of Barak (2017) who stress the importance to promote web 2.0 environments to collaborate in decentralized environments. Among the variables to be considered in the instructional design of the learning platform, Mirriahi et al. (2015) point out the need to consider: monitoring, feedback and evaluation. Online students would like to receive "more comprehensive feedback to improve performance" (Gaytan, 2015, p. 56). In this regard, online course designers should consider generating different types of activities besides discussion or dialogue (Lim, Jeong, Hall \& Freed, 2017; Khan, Egbue, Palkie, \& Madden, 2017). 


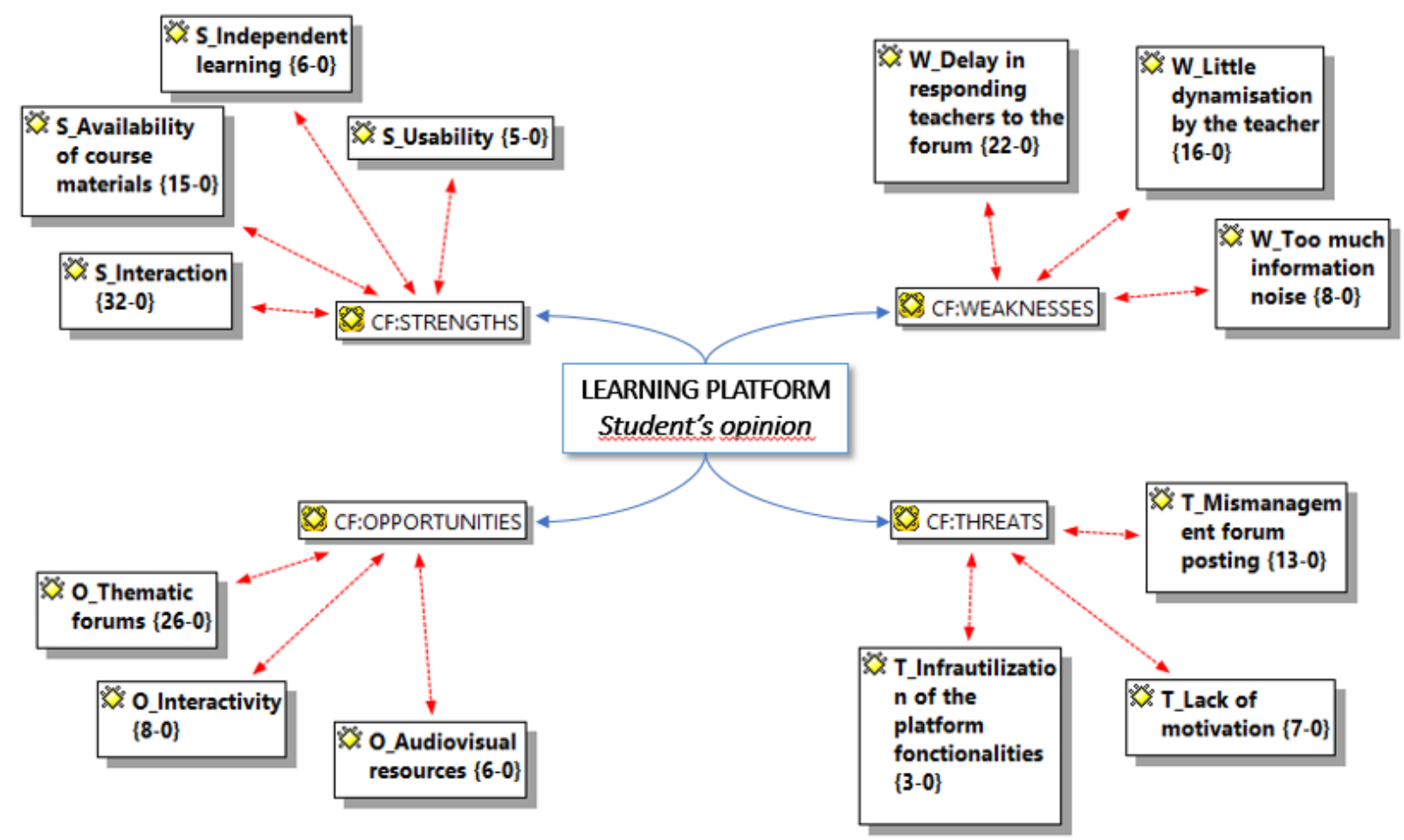

Figure 9. Learning Platform Student's Opinion (open questions analysis)

The forum, chat and webconference centralize the communication process inside the platform. Participants have a positive opinion about the use of webconference to answer questions, as well as the possibility to review off-line later. It is suggested the creation of videotutorials to facilitate the work with the contents (Pérez-Navio, Rodriguez \& Carmona, 2015). The use of synchronous communication tools (chat and webconference) provide the possibility of a better knowledge of the participants resulting in online discussions (Falloon, 2011).

The analysis of open questions raises the need for an educational model that optimizes the possibilities of working the transdisciplinary knowledge, through a creative and rational use of the basic tools of the learning platform (forums, chat and webconference). In this regard, it is suggested by participants to improve the response time to questions raised in the forum, and to propose topics for discussion to increase teachers dynamization. Considering all this information, Piscitelli (2015) maintain that, to create tomorrow's universities, the problem is not technological but epistemological, discursive and ideological. It is important to generate a process of research and innovation using learning platforms and building strategies for initial and continuing training of educators.

\section{BIODATA and CONTACT ADDRESSES of AUTHORS}

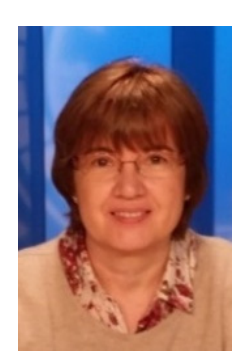

Maria Luz CACHEIRO-GONZALEZ has a Ph.D. in Education Sciences from the UNED, Spain. She received her B.A. Degree in Education and Psychology from the Complutense University, Madrid, Spain. She is Professor at the Faculty of Education at the UNED, Spain. Coordinator of the Master in Strategies and Technologies for Teaching Role in Multicultural Society Education Department. Coordinator of the Media, Technology and Resources Socio Intervention Level of Social Education Degree. Among his current research are "Evaluating web resources" and "the digital portfolio as a strategy for teaching and learning". 
Dr. Maria Luz CACHEIRO-GONZALEZ

Instructional Design Department, School of Education

Universidad Nacional de Educacion a Distancia (UNED)

C/ Juan del Rosal, 14, 28040 Madrid, Spain

Phone: +34913988878

E-mail: mlcacheiro@edu.uned.es

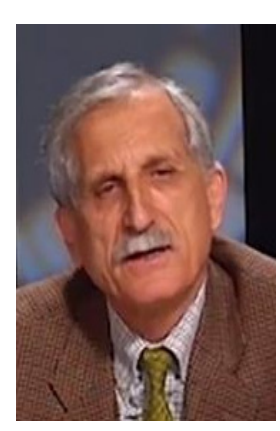

Antonio MEDINA-RIVILLA has a Ph.D. on Philosophy and Educational Sciences. He is Emeritus Professor at the UNED, Spain, in the area of Teaching and School Organization, and has thus been Director of Department for more than 25 years. $\mathrm{He}$ has directed over 100 doctoral theses and numerous research papers in Spanish and international context. He has developed numerous national and international R\&D projects, with a great impact on scientific network discussion (ECER, ISAAT, RIAICES, etc.). Professor Honoris Causa of IUNIR (Argentina) and the University of Santander (Mexico) in 2015, and has won special recognition for their collaboration professor and researcher at the University of Latvia, Riga (Latvia) in 2015.

\section{Dr. Antonio MEDINA-RIVILLA}

Instructional Design Department, School of Education

Universidad Nacional de Educacion a Distancia (UNED)

C/ Juan del Rosal, 14, 28040 Madrid, Spain

Phone: +34913986969

E-mail: amedina@edu.uned.es

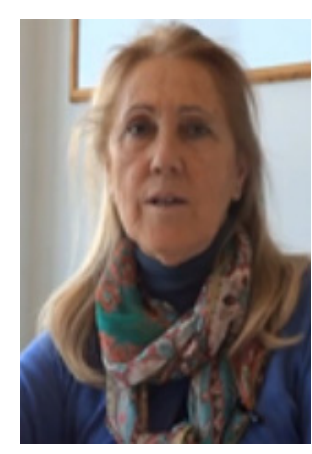

Maria Concepcion DOMINGUEZ-GARRIDO has a Ph.D. in Social Sciences, and Degree in Pedagoy and Geography and History. She has been Professor Jean Monnet for the European Union. She has been full-time professor in the Complutense University of Madrid, Spain. She develops its work in the UNED in the area of Teaching of Social Sciences, where she is part of various committees. She has coordinated numerous projects $\mathrm{R} \& \mathrm{D}$ projects, and coordinates an annual project within the Call for Research Networks for Educational Innovation (UNED) with great impact on the adaptation of the own university methodology UNED to EHEA guidelines. She is the Coordinator of the Master International Educational Treatment of Diversity (UNED). She has numerous publications in the form of articles and books, and she participates in the ECER, ISAAT and RIAICES networks.

Dr. Maria Concepcion DOMINGUEZ-GARRIDO

Instructional Design Department, School of Education

Universidad Nacional de Educacion a Distancia (UNED)

C/ Juan del Rosal, 14, 28040 Madrid, Spain

Phone: +34913986970

E-mail: cdominguez@edu.uned.es

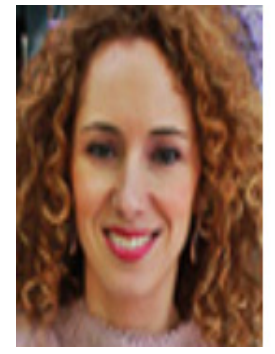

Maria C. MEDINA-DOMINGUEZ has a Ph. International D. in Education, and Degree in Law by Complutense University of Madrid. Training consultancy. She has worked as Project Manager Training and Development in several consulting firms worldwide, directing and designing programs to attract and develop talent in different professional realities. She has published books: Leadership Training in Emotional Intelligence and Talent Management, Teaching applied to Health Sciences, as well as chapters on emotional dimension of leadership and emotional intelligence and coaching 
as a tool for the development of emotional competencies. He has been invited speaker at national and international conferences (ECER, RIAICES, UVU). She has been co-director of the course of teacher training: Europe in the field of development cooperation.

Dr. Maria C. MEDINA-DOMINGUEZ

Institute of Professional Competencies

Universidad Antonio de Nebrija

C/ Santa Cruz de Marcenado, 27, 28015 Madrid, Spain

Phone: +34 620515563

E-mail: mcastanar@nebrija.es

\section{REFERENCES}

Adams, S., Cummins, M., Davis, A., Freeman, A., Hall, C., \& Ananthanarayanan, V. (2017). NMC Horizon Report: 2017 Higher Education Edition. Austin, Texas: The New Media Consortium. Retrieved from http://cdn.nmc.org/media/2017-nmc-horizon-report-he-EN.pdf

Almarashdeh, I. (2016). Sharing instructors experience of learning management system: A technology perspective of user satisfaction in distance learning course. Computers in Human Behavior, 63, 249-255

Altınay, Z. (2017). Evaluating peer learning and assessment in online collaborative learning environments. Behaviour \& Information Technology, 36(3), 312-320. doi: https://doi.org/10.1080/0144929X.2016.1232752

Altunoglu, A. (2017). Initial perceptions of open higher education students with learner management systems. Turkish Online Journal of Distance Education (TOJDE), 18(3), 96-104. doi: https://doi.org/10.17718/tojde.328939

Arasaratnam, L. A. \& Northcote, M. (2017). Community in Online Higher Education: Challenges and Opportunities. The Electronic Journal of e-Learning, 15(2), 188-198.

Baleghi, S., Ayub, A. F. M., Mahmud, R., \& Daud, S. M. (2017). The influence of system interactivity and technical support on learning management system utilization. Knowledge Management \& $E$ Learning, 9(1), 50-68. Retrieved from http://www.kmel-journal.org/ojs/index.php/onlinepublication/article/view/696/338

Barak, M. (2017). Science teacher education in the twenty-first century: A pedagogical framework for technology-integrated social constructivism. Research in Science Education, 47(2), 283-303. doi: https://dx.doi.org/10.1007/s11165-015-9501-y

Bartolomé, A., Garcia, R. \& Aguaded, I. (2018). Blended Learning: Panorama y Perspectivas [Blended Learning: Landscape and Perspectives]. RIED, Revista Iberoamericana de Educacion a Distancia, 21(1), 33-56.

Bates, A. W. (2015). Teaching in A Digital Age. UK: BC Open Textbooks. Retrieved from https://opentextbc.ca/teachinginadigitalage

Benedetti, C. (2015). Online instructors as thinking advisors: a model for Online Learning. Third Quarter, 12(4), 171-176.

Bin, A. (2017). Faculty Perceptions of the Educational Value of Learning Management Systems. Doctoral dissertation, University of Sheffield. Retrieved from http://etheses.whiterose.ac.uk/19134/ 
Bousbahi, F., \& Alrazgan, M. S. (2015). Investigating IT faculty resistance to learning management system adoption using latent variables in an acceptance technology model. The Scientific World Journal, 1-11. doi: http://dx.doi.org/10.1155/2015/375651

Brazuelo, F. \& Cacheiro-González, M.L. (2015). Estudio de adaptabilidad para dispositivos moviles en plataformas MOOC [Adaptability study for mobile devices on MOOC platforms]. RED, Revista de Educacion a Distancia, 47(1), 1-13. doi: https://dx.doi.org/10.6018/red/47/1

Brown, M., Dehoney, J. \& Millichap, N. (2015). What's Next for the LMS? Educause Review, 50(4), 4051. Retrieved from https://er.educause.edu/ /media/files/article-downloads/erm1543.pdf

Cabero, J. (2014). La formacion del profesorado en TIC: modelo TPACK [The training of teachers on ICT: TPACK model]. Sevilla: Secretariado de Recursos Audiovisuales y Nuevas Tecnologias de la Universidad de Sevilla.

Cacheiro, M.L. (2011). Recursos educativos TIC de informacion, colaboracion y aprendizaje [ICT Educational Resources for Information, Collaboration and Learning]. Pixel-Bit, Revista de Medios y Comunicacion, 39, 69-81. Retrieved from http://acdc.sav.us.es/pixelbit/images/stories/p39/06.pdf

Cho, Y.S. (2011). Diversification of learning platforms. Moscow: ITE-UNESCO. Retrieved from http://unesdoc.unesco.org/images/0021/002144/214486e.pdf

Chugh, R., Ledger, S., \& Shields, R. (2017). Curriculum design for distance education in the tertiary sector. Turkish Online Journal of Distance Education (TOJDE), 18(2),1-15. doi: http://dx.doi.org/10.17718/tojde.306552

Conner, M.L. (2013). Informal learning. Retrieved from http://marciaconner.com/resources/informallearning/

Creswell, J. W. (2012). Educational research: Planning, conducting, and evaluating quantitative and Qualitative Research. Upper Saddle River, NJ: Prentice Hall.

Dahlstrom, E., Brooks, D. Ch., \& Bichsel, J. (2014). The Current Ecosystem of Learning Management Systems in Higher Education: Student, Faculty, and IT Perspectives. Research report. Louisville, CO: ECAR, Educause Center for Analysis and Research. Retrieved from http://www.educause.edu/ecar

Duran, A., Cornejo, J., \& Flores, J. (2017). Competitive advantages with the use of ICT (moodle) in the new curriculum at the University of Guadalajara, México. Competition Forum, 15(2), 319-323.

Falloon, G. (2011). Making the connection: Moore's Theory of transactional distance and its relevance to the use of a virtual classroom in postgraduate online teacher education. Journal of Research on Technology in Education, 43(3), 187-209.

Fields, A., Lai, K.W., Gibbs, J., Kirk, A. \& Vermunt, J. (2016). The transformation of an online learning community from an organized facility to an organic Fraternity. Distance Education, 37(1), 60-72.

Garcia-Aretio, L. (2017). Educacion a distancia y virtual: calidad, disrupcion, aprendizajes adaptativo y movil [Distance and virtual education: quality, disruption, adaptive and mobile learning.]. RIED. Revista Iberoamericana de Educacion a Distancia, 20(2), 9-25. doi: https://dx.doi.org/10.5944/ried.20.2.18737

Garcia-Cabrero, B. (2009). Manual de métodos de investigacion para las ciencias sociales. Un enfoque de enseñanza basado en proyectos [Manual of research methods for the social sciences. A project-based teaching approach]. México: Manual Moderno.

Garrison, D.R. \& Anderson, T. (2005). El e-learning en el siglo XXI [The elearning in the XXI century]. Barcelona: Octaedro. 
Garrison, D.R. \& Cleveland, M. (2005). Facilitating Cognitive Presence in Online Learning: Interaction Is Not Enough. The American Journal of Distance Education, 19(3), 133-148. doi: https://doi.org/10.1207/s15389286ajde1903_2

Gaytan, J. (2015). Comparing Faculty and Student Perceptions Regarding Factors that affect Student Retention in Online Education. The American Journal of Distance Education, 29, 56-66.

Gharmallah, M. (2017). The Effect of Using Online Discussion Forums on Students' Learning. TOJET: The Turkish Online Journal of Educational Technology, 16(1), 164-176. Retrieved from http://www.tojet.net/articles/v16i1/16115.pdf

Gomez, J. (ed.) (2016). UNIVERSITIC 2016. Análisis de las TIC en las Universidades Españolas [TIC Analysis in Spanish Universities]. Madrid: CRUE Universidades Españolas.

Gomez, P.; Barbera, E. \& Fernández, F. (2016). Measuring teachers and learners' perceptions of the quality of their online learning experience. Distance Education, 37(2), 146-163. doi: https://doi.org/10.1080/01587919.2016.1184396

Guedez, M. M., \& Navea, L. C. (2014). La interaccion comunicativa en los foros de discusion de un entorno virtual de enseñanza y aprendizaje [The communicative interaction in the forums of discussion of a virtual environment of teaching and learning]. Accion Pedagogica, 23(1), 48-58. Retrieved from http://www.saber.ula.ve/handle/123456789/40899

Gurtler, L. \& Huber, G.L. (2007). Modos de pensar y estrategias de la investigacion cualitativa [Ways of thinking and strategies of qualitative research]. Liberabit, 13, 37-52.

Henderson, M., Selwyn, N. \& Aston, R. (2017). What works and why? Student perceptions of 'useful' digital technology in university teaching and learning. Studies in Higher Education, 42(8), 15671579. doi: https://dx.doi.org/10.1080/03075079.2015.1007946

Hernández-Sampieri, R., Fernández-Collado, C. \& Baptista-Lucio, P. (2010). Metodologia de la investigacion [Research methodology]. México: McGraw-Hill.

Holzweias, P.C., Joyner, S.A., Fuller, M.B., Henderson, S. \& Young, R. (2014). Online graduate student's perceptions of best learning experiences. Distance Education, 35(3), 311-323.

INTEF, National Institute of Educational Technologies and Teacher Training, Spain (2017). Common Digital Competence Framework For Teachers. Madrid: MECD, Ministry of Education, Culture and Sport, Spain. Retrieved from http://aprende.educalab.es/wpcontent/uploads/2017/12/2017_1024-Common-Digital-Competence-Framework-ForTeachers.pdf

Ioannou, A. Demetriou, S. \& Mama, M. (2014). Exploring factors influencing collaborative knowledge construction in online discussions: student facilitation and quality of initial postings. The American Journal of Distance Education, 28, 183-195.

ITU-UNESCO (2014). Partnership on measuring ICT for development final WSIS targets review achievements, challenges and the way forward. Retrieved from http://www.itu.int/en/ITUD/Statistics/Documents/publications/wsisreview2014/WSIS2014_review.pdf

Jain, M. \& Tyagi, R. (2017). Education standard can be improved by integrating. ICT in Education. International Education \& Research Journal, 3(10), 77-80. Retrieved from http://ierj.in/journal/index.php/ierj/article/view/1452/1383

Johnson, L., Adams, S., Cummins, M., Estrada, V., Freeman, A., \& Hall, C. (2016). NMC Horizon Report: 2016 Higher Education Edition. Austin, Texas: The New Media Consortium. 
Ju-Yin, T, \& Yen-Chen, Y. (2016). College Students' Perspectives of E-Learning System Use in High Education. Asian Journal of Education and Training, 2(2), 53-62. Retrieved from http://www.asianonlinejournals.com/index.php/EDU/article/viewFile/889/pdf

Karataş, S., Yılmaz, A. B., Dikmen, C. H., Ermiş, U. F., \& Gurbuz, O. (2017). Interaction in distance education environments: A trend analysis. Quarterly Review of Distance Education, 18(1), 63.

Keane, T., Keane, W. F., \& Blicblau, A. S. (2016). Beyond traditional literacy: Learning and transformative practices using ICT. Education and Information Technologies, 21(4), 769-781. doi: https://dx.doi.org.ezproxy.uned.es/10.1007/s10639-014-9353-5

Kebble, P.G. (2017). Assessing Online Asynchronous Communication Strategies Designed to Enhance Large Student Cohort Engagement and Foster a Community of Learning. Journal of Education and Training Studies, 5(8); 92-100. doi: https://doi.org/10.11114/jets.v5i8.2539

Khan, A., Egbue, O., Palkie, B., \& Madden, J. (2017). Active learning: Engaging students to maximize learning in an online course. Electronic Journal of E-Learning, 15(2), 107-115.

Knyazeva, S. (2016) (ed.). Futures for Higher Education and ICT: Changes Due to the Use of Open Content. Moscow: ITE-UNESCO. Retrieved from http://iite.unesco.org/pics/publications/en/files/3214745.pdf

Krathwohl, D.R. (2002). Revising Bloom's Taxonomy. Theory into practice, 41(4), 212-218. Retrieved from http://rt3region7.ncdpi.wikispaces.net/file/view/8+Perspectives+on+RBT.pdf

Kurucay, M. \& Inan, F.A. (2017). Examining the effects of learner-learner interactions on satisfaction and learning in an online undergraduate course. Computers \& Education, 115, 20-37.

Kwon, K., \& Park, S. J. (2017). Effects of discussion representation: Comparisons between social and cognitive diagrams. Instructional Science, 45(4), 469-491. doi: https://doi.org/10.1007/s11251017-9412-6

Lim, J., Jeong, A. C., Hall, B. M., \& Freed, S. (2017). Intersubjectivity and discussion characteristics in online courses. Quarterly Review of Distance Education, 18(1), 29-44.

Lopez, E. \& Camilli, C. (2014). Métodos mixtos de investigacion en modalidad b-learning: análisis de la comunicacion asincronica [Mixed methods research in b-learning modality: asynchronous communication analysis]. Historia y Comunicacion Social, 19, 403-415. doi: http://dx.doi.org/10.5209/rev_HICS.2014.v19.44966

Lyashenko, M.S. \& Frolova, N.H. (2014). LMS projects: A platform for intergenerational e-learning collaboration. Education and Information Technologies, 19, 495-513. doi: https://dx.doi.org/10.1007/s10639-014-9333-9

Ma, J., Han, X., Yang, J., \& Cheng, J. (2015). Examining the necessary condition for engagement in an online learning environment based on learning analytics approach: The role of the instructor. The Internet and Higher Education, 24, 26-34. doi: https://doi.org/10.1016/j.iheduc.2014.09.005

Maita, M. \& Navea, L.C. (2014). La interaccion comunicativa en los foros de discusion de un entorno virtual de enseñanza y aprendizaje [The communicative interaction in the forums of discussion of a teaching and learning virtual environment]. Accion Pedagogica, 23, 48-58.

Marin, V., Sampedro, B. E., \& Vega, E. (2017). Percepciones de los estudiantes universitarios sobre las plataformas de formacion. estudio de caso [Perceptions of University Students about Training Platforms. Case Study]. Revista Iberoamericana De Educacion a Distancia, 20(1), 283-303. doi: https://dx.doi.org/10.5044/ried.20.1.16518 
Martin, F., Ahlgrim, L. \& Budhrani, K. (2017) Systematic Review of Two Decades (1995 to 2014) of Research on Synchronous Online Learning. American. Journal of Distance Education, 31(1), 3-19. doi: https://doi.org/10.1080/08923647.2017.1264807

Medina, A. \& Dominguez, M.C. (2015). Modelo didáctico-tecnologico para la innovacion educativa [Didactic-technological model for educational innovation]. In M.L. Cacheiro-González, C. Sánchez \& J.M. González (coords.), Recursos tecnologicos en contextos educativos [Technological resources in educational contexts]. Madrid: UNED.

Medina, A., Cacheiro, M.L. \& Medina-Medina, A. (2015). Caracteristicas de la práctica docente: el proceso de profesionalizacion [Characteristics of teaching practice: the professionalization process]. In A. Medina \& M.C. Dominguez, Didáctica. Formacion básica para profesionales de la educacion [Didactics. Basic training for education professionals]. Madrid: Universitas.

Medina, A., Pérez, L. \& Campos, B. (2014). Elaboracion de planes y programas de formacion del profesorado en didácticas especiales [Preparation of teacher training plans and programs in special didactics]. Madrid: UNED.

Mirriahi, N.; Alonzo, D.; McIntyre, S., Kligyte, G. \& Fox, B. (2015). Blended Learning innovations: Leadership and change in one Australian Institutions. International Journal of Education and Development using Information and Communication Technology, 11(1), 4-16.

Mishra, P. \& Koehler, M.J. (2006). Technological Pedagogical Content Knowledge: A new framework for teacher knowledge. Teachers College Record, 108(6), 1017-1054. Retrieved from http://punya.educ.msu.edu/publications/journal_articles/mishra-koehler-tcr2006.pdf

Moreira, J.A., Henriques, S., Gouláo, M.F. \& Barros, D. (2017). Digital Learning in Higher Education: A Training Course for Teaching Online - Universidade Aberta, Portugal. Open Praxis, 9(2), 253 263. Retrieved from https://openpraxis.org/index.php/OpenPraxis/article/view/539/306

Moreno, V., Cavazotte, F., Alves, I. (2017). Explaining university students' effective use of e-learning platforms. British Journal of Educational Technology, 48(4), 995-1009. doi: https://dx.doi.org/10.1111/bjet.12469

Murua, I., Cacheiro, M.L. \& Gallego, D. (2014). Las cibercomunidades de aprendizaje (cCA) en la formacion del profesorado [The learning cybercommunities (cCA) in teacher training]. Red, Revista de Educacion a Distancia, 43(15), 12-29. Retrieved from http://www.um.es/ead/red/43/gallego_et_al.pdf

Oproiu, G.C. (2015). A Study about Using E-learning Platform (Moodle) in Univeristy Teaching Process. Procedia-Social and Behavioral Sciences, 180, 426-432.

Pavel, A.P.; Fruth, A. \& Neacsu, M.N. (2015). ICT and E-Learning: Catalysts for Innovation and Quality in Higher Education. Procedia Economics and Finance, 23, 704-711. doi: https://doi.org/10.1016/S2212-5671(15)00409-8

Pérez-Navio, E., Rodriguez, J. \& Carmona, M. (2015). El uso de mini-videos en la práctica docente universitaria [The use of mini-videos in university teaching practice]. Edmetic, 4(2), 51-70.

Pilli, O. (2014). LMS Vs. SNS: Can Social Networking Sites Act as a Learning Management Systems? American International Journal of Contemporary Research, 4(5), 90-97

Piscitelli, A. (2015). ¿Está cambiando la tecnologia la Universidad? Humanidades digitales y nuevo normal educativo [Is the University changing technology? Digital humanities and new normal education]. Telos, 101,13-22. 
Prendes, M.P. \& Gutiérrez, I. (2013). Competencias tecnologicas del profesorado en las universidades españolas [Technological competences of teachers in Spanish universities]. Revista de Educacion, 361, 196-222.

Puentedura, R. (2016, 12 July). How to Apply the SAMR Model with Ruben Puentedura [youtube]. Recuperado de https://www.youtube.com/watch?v=ZQTx2UQQvbU

Puentedura, R.R. (December 12, 2014). Technology In Education: An Integrated Approach. Retrieved from

http://www.hippasus.com/rrpweblog/archives/2014/12/12/TechnologyInEducation_AnIntegrate dApproach.pdf

Reichardt, Ch.S. \& Cook, T.D. (1986). Hacia una superacion del enfrentamiento entre los métodos cualitativos y cuantitativos [Towards an overcoming of the clash between qualitative and quantitative methods]. In Ch.S. Reichardt \& T.D. Cook, Métodos cualitativos y cuantitativos en investigacion evaluativa (pp. 25-58) [Qualitative and quantitative methods in evaluation research]. Madrid: Morata.

Rienties, B. \& Toetenel, L. (2016). The impact of learning design on student behavior, satisfaction and performance: A cross-institutional comparison across 151 modules. Computers in Human Behavior, 60, 333-341. doi: https://dx.doi.org/10.1016/j.chb.2016.02.074

Sáez, J.M., Dominguez, M.C., Ruiz, J.M. \& Belando, M. (2014). Análisis del uso de los sistemas de gestion de aprendizaje en el desarrollo profesional docente desde una perspectiva práctica en la Escuela Complutense [Analysis of the use of learning management systems in teacher professional development from a practical perspective in the Complutense School]. Bordon, 66(3), 133-148. doi: https://dx.doi.org/10.13042/Bordon.2014.66309

Schmidt, D. A., Baran, E., Thompson, A. D., Mishra, P., Koehler, M. J., y Shin, T. S. (2009). Technological Pedagogical Content Knowledge (TPACK). The Development and Validation of an Assessment Instrument for Preservice Teachers. Journal of Research on Technology in Education, 42(2), 123-149. doi: https://doi.org/10.1080/15391523.2009.10782544

Scoppio, G. \& Luyt, I. Educ Inf Technol (2017). Mind the gap: Enabling online faculty and instructional designers in mapping new models for quality online. Education and Information Technologies, 22(3), 725-746. doi: https://doi.org/10.1007/s10639-015-9452-y

Selwyn, N. (2016). Digital downsides: exploring university students' negative engagements with digital technology. Teaching in Higher Education, 21(8), 1006-1021. doi: https://dx.doi.org/10.1080/13562517.2016.1213229

Shaw, C., Larson, R. \& Sibdari, S. (2014). An asynchronous, personalized learning platform-Guided Learning Pathways (GLP). Creative Education, 5, 1189-1204. doi: https://dx.doi.org/10.4236/ce.2014.513135

Valles, M. (1997). Técnicas cualitativas de investigacion social. Reflexion metodologica y práctica profesional [Qualitative techniques of social research. Methodological reflection and professional practice]. Madrid: Sintesis.

Xiao, J. (2017). Learner-content interaction in distance education: The weakest link in interaction research. Distance Education, 38(1), 123-135. doi: https://doi.org/10.1080/01587919.2017.1298982

Yot, C. \& Marcelo, C. (2017). University students self-regulated learning using digital technologies. International Journal of Educational Technology in Higher Education, 14, 1-18. doi: https://doi.org/10.1186/s41239-017-0076-8 
Zagalsky, A., Feliciano, J., Storey, M.A., Zhao, Y. \& Wang, W. (2015). The Emergence of GitHub as a Collaborative Platform for Education. Motivation and Dynamics of the Open Classroom. CSCW 2015, March 14-18, 2015. Vancouver, BC, Canada.

Zanjani, N., Edwards, S. L., Nykvist, S., \& Geva, S. (2016). LMS Acceptance: The Instructor Role. The Asia-Pacific Education Researcher, 25(4), 519-526.

Zapata, M. (2011). Evaluacion de la calidad en entornos sociales de aprendizaje [Evaluation of quality in social learning environments]. RED, Revista de Educacion a Distancia, 29, 1-10.9

Zhu, Y., Au, W. \& Yates, G. (2016). University student's self-control and self-regulated learning in a blended course. Internet and Higher Education, 30, 54-62. doi: https://doi.org/10.1016/j.iheduc.2016.04.001

Zimmerman, B.J. (1990). Self-Regulated Learning and Academic Achievement: An Overview. Educational Psychologist, 25(1), 3-17. 


\section{APPENDIX}

\section{Questionnaire Responses (Percentages)}

\begin{tabular}{|c|c|c|c|c|c|c|}
\hline Items & 1 & 2 & 3 & 4 & 5 & 6 \\
\hline 1. The learning platform motivates for the learning of the subject. & 3,6 & 9,0 & 13,5 & 29,7 & 36,0 & 8,1 \\
\hline 2. The learning platform facilitates the availability of course materials. & 4,5 & 9,0 & 5,4 & 31,5 & 31,5 & 18,0 \\
\hline 3. The learning platform promotes autonomous learning. & 2,7 & 6,3 & 4,5 & 27,9 & 39,6 & 18,9 \\
\hline $\begin{array}{l}\text { 4. The learning platform has been successfully incorporated by the } \\
\text { teaching staff. }\end{array}$ & 4,5 & 9,0 & 14,4 & 35,1 & 31,5 & 5,4 \\
\hline $\begin{array}{l}\text { 5. The learning platform requires effort to locate the relevant } \\
\text { information. }\end{array}$ & 6,3 & 16,2 & 21,6 & 24,3 & 27,0 & 4,5 \\
\hline $\begin{array}{l}\text { 6. The learning platform is a complement to the classic materials of the } \\
\text { course. }\end{array}$ & 6,3 & 16,2 & 21,6 & 24,3 & 27,0 & 4,5 \\
\hline 7. The learning platform encourages critical thinking. & 5,4 & 9,0 & 16,2 & 43,2 & 18,0 & 8,1 \\
\hline $\begin{array}{l}\text { 8. The learning platform favors the interaction between the different } \\
\text { agents of the course. }\end{array}$ & 2,7 & 6,3 & 12,6 & 35,1 & 27,9 & 15,3 \\
\hline $\begin{array}{l}\text { 9. The use of the learning platform should be mandatory in distance } \\
\text { education. }\end{array}$ & 5,4 & 2,7 & 21,6 & 31,5 & 12,6 & 26,1 \\
\hline $\begin{array}{l}\text { 10. The didactic guide offers the key aspects for the development of the } \\
\text { subject. }\end{array}$ & 0 & 7,8 & 8,9 & 41,1 & 20 & 21,1 \\
\hline $\begin{array}{l}\text { 11. The contents selected are relevant to an in-depth knowledge of the } \\
\text { subject. }\end{array}$ & 4,4 & 5,6 & 13,3 & 41,1 & 23,3 & 11,1 \\
\hline $\begin{array}{l}\text { 12. Online supplementary documents add value to the course's classic } \\
\text { materials. }\end{array}$ & 3,3 & 4,4 & 8,9 & 41,1 & 26,7 & 15,6 \\
\hline $\begin{array}{l}\text { 13. The tasks of the learning platform allow to deepen the mastery of the } \\
\text { contents. }\end{array}$ & 3,3 & 7,8 & 7,8 & 27,8 & 35,6 & 16,7 \\
\hline $\begin{array}{l}\text { 14. The self-assessment activities in the learning platform promote the } \\
\text { acquisition of the knowledge of the subject. }\end{array}$ & 2,2 & 6,7 & 10 & 36,7 & 21,1 & 18,9 \\
\hline $\begin{array}{l}\text { 15. The feedback to the tasks sent in the platform contributes to the } \\
\text { improvement of the learning. }\end{array}$ & 2,2 & 7,8 & 4,4 & 31,1 & 25,6 & 28,9 \\
\hline $\begin{array}{l}\text { 16. The platform teaching team forum offers possibilities to comment } \\
\text { basic contents of the subject. }\end{array}$ & 5,6 & 3,3 & 17,8 & 41,1 & 21,1 & 6,7 \\
\hline $\begin{array}{l}\text { 17. The platform students' forum (cafeteria) offers a space for } \\
\text { collaborative learning. }\end{array}$ & 3,3 & 0 & 12,2 & 51,1 & 12,2 & 12,2 \\
\hline $\begin{array}{l}\text { 18. The platform chat facilitates the agile resolution of your doubts in } \\
\text { your learning. }\end{array}$ & 4,4 & 7,8 & 16,7 & 35,6 & 14,4 & 6,7 \\
\hline $\begin{array}{l}\text { 19. The platform web conferencing favors the creation of an affective } \\
\text { bond with the teacher throughout the learning process. }\end{array}$ & 2,2 & 5,6 & 14,4 & 30 & 17,8 & 21,1 \\
\hline $\begin{array}{l}\text { 20. The participation in networks of teacher innovation through the } \\
\text { platform allows to continue reflecting on the subject in a broader } \\
\text { context. }\end{array}$ & 0 & 1,1 & 6,7 & 48,9 & 25,6 & 14,4 \\
\hline $\begin{array}{l}\text { 21. The learning platform has introduced a new culture in distance } \\
\text { education processes. }\end{array}$ & 3,3 & 3,3 & 5,6 & 34,3 & 32,2 & 21,1 \\
\hline
\end{tabular}




\begin{tabular}{|c|c|c|c|c|c|c|}
\hline $\begin{array}{l}\text { 22. Teachers use the learning platform to respond to the needs of } \\
\text { distance education. }\end{array}$ & 6,7 & 14,4 & 13,3 & 33,3 & 18,9 & 13,3 \\
\hline $\begin{array}{l}\text { 23. The learning platform facilitates the relationship between all course } \\
\text { participants. }\end{array}$ & 2,2 & 4,4 & 15,6 & 37,8 & 22,2 & 17,8 \\
\hline $\begin{array}{l}\text { 24. The learning platform favors the creation of a scenario of possibilities } \\
\text { of collaboration between equals. }\end{array}$ & 1,1 & 6,7 & 13,3 & 35,6 & 27,8 & 15,6 \\
\hline $\begin{array}{l}\text { 25. The learning platform fosters a climate of didactic interaction } \\
\text { between teachers and students. }\end{array}$ & 3,3 & 8,9 & 14,4 & 34,4 & 25,6 & 13,3 \\
\hline $\begin{array}{l}\text { 26. The learning platform enables the creation of learning communities } \\
\text { among students. }\end{array}$ & 2,2 & 3,3 & 20 & 37,8 & 21,1 & 15,6 \\
\hline $\begin{array}{l}\text { 27. The learning platform enables a fruitful dialogue with teachers for } \\
\text { professional practice. }\end{array}$ & 4,4 & 13,3 & 16,7 & 41,1 & 17,8 & 6,7 \\
\hline $\begin{array}{l}\text { 28. Through the learning platform, strong links with other students are } \\
\text { encouraged for future projects. }\end{array}$ & 4,4 & 12,2 & 33,3 & 28,9 & 13,3 & 7,8 \\
\hline $\begin{array}{l}\text { 29. The learning platform promotes a collaborative learning style of } \\
\text { interest for your professional practice. }\end{array}$ & 2,2 & 5,6 & 20 & 42,2 & 17,8 & 12,2 \\
\hline $\begin{array}{l}\text { 30. The training platform promotes a collaborative learning style of } \\
\text { interest for their professional practice. }\end{array}$ & 2,7 & 5,4 & 17,1 & 38,7 & 24,3 & 11,7 \\
\hline $\begin{array}{l}\text { 31. Satisfaction is perceived in using the learning platform as a means to } \\
\text { improve ongoing training processes. }\end{array}$ & 7,8 & 3,3 & 13,3 & 47,8 & 21,1 & 6,7 \\
\hline $\begin{array}{l}\text { 32. The use of the learning platform with the classical materials (texts, } \\
\text { ebook, guides, etc.) is appropriately combined. }\end{array}$ & 1,1 & 5,6 & 8,9 & 54,4 & 20 & 10 \\
\hline $\begin{array}{l}33 \text { The learning platform constitutes an essential didactic resource in } \\
\text { distance education. }\end{array}$ & 1,1 & 0 & 4,4 & 23,3 & 25,6 & 45,6 \\
\hline
\end{tabular}

$1=$ strongly disagree, $2=q u i t e$ disagree, $3=$ somewhat disagree, 4=somewhat agree, $5=q u i t e$ agree, $6=$ strongly agree 